\title{
Unusual population explosion of the giant jellyfish Nemopilema nomurai (Scyphozoa: Rhizostomeae) in East Asian waters
}

\author{
Masato Kawahara $^{1, *}$, Shin-ichi Uye ${ }^{1}$, Kohzoh Ohtsu' ${ }^{2}$, Hitoshi Iizumi ${ }^{3}$ \\ ${ }^{1}$ Graduate School of Biosphere Sciences, Hiroshima University, 4-4 Kagamiyama 1 Chome, Higashi-Hiroshima 739-8528, Japan \\ ${ }^{2}$ Oki Marine Biological Station, Department of Biological Science, Shimane University, 194 Kamo, Okinoshima-cho, \\ Oki 685-0024, Japan \\ ${ }^{3}$ Japan Sea National Fisheries Research Institute, 5939-22 Suido-cho 1 Chome, Niigata City, Niigata 951-8121, Japan
}

\begin{abstract}
A population explosion of the giant jellyfish Nemopilema nomurai (Scyphozoa: Rhizostomeae) occurred in the Sea of Japan in 2002 and 2003, causing severe damage to fisheries. There was a further population explosion in 2004, but on a much smaller scale. In both years, young medusae began to appear in the Tsushima and Korea Strait in July and August, followed by a northward expatriation in the Tsushima Current to the northern Sea of Japan. We obtained scyphistomae of this species by artificial fertilization, and reared them to the young medusa stage in the laboratory. Asexual reproduction of scyphistomae occurred by means of podocyst formation. A thermal increase from 13 to $23^{\circ} \mathrm{C}$ induced strobilation, followed by liberation of 3 to 7 ephyrae from a strobila. The ephyrae developed to metephyrae having a complex canal system and characteristically possessing long reddish purple filiform appendages. By $40 \mathrm{~d}$ post-liberation, the metephyrae had grown to medusae in which the central mouth had closed and been replaced by numerous mouthlets on both oral wings and scapulets. The results from both laboratory-rearing experiments and field investigations were combined to construct the seasonal life cycle and geographical distribution of $N$. nomurai in eastern Asian waters. Possible causes for the mass occurrence of N. nomurai, which has tended to be more frequent in the last decade, are discussed.
\end{abstract}

KEY WORDS: Nemopilema nomurai $\cdot$ Rhizostomeae $\cdot$ Mass occurrence $\cdot$ Geographical distribution · Fishery impacts $\cdot$ Life cycle $\cdot$ Sea of Japan

\section{INTRODUCTION}

Nemopilema nomurai (Cnidaria: Scyphozoa: Rhizostomeae) is one of the largest of all jellyfish species, attaining a bell diameter of ca. $2 \mathrm{~m}$ and a wet weight of ca. $200 \mathrm{~kg}$ (Kishinouye 1922, Omori \& Kitamura 2004). $N$. nomurai was first described by Kishinouye (1922) as a new species and genus based on specimens collected in the Sea of Japan. Uchida (1954) later regarded Nemopilema as a junior synonym of Stomolophus without any plausible reason and referred to this species as $S$. nomurai. Many subsequent Japanese researchers (Shimomura 1959, Yamada 1997) adopted this species name. Furthermore, Kramp (1961) and Hon et al. (1978) regarded this species as a synonym of
S. meleagris. However, N. nomurai is very different from $S$. meleagris in morphology, size and geographic range. Omori \& Kitamura (2004) recently revised the taxonomy of 3 rhizostome species from Japanese waters and concluded that this species should be reassigned to the genus Nemopilema.

Little is known about the biology and ecology of Nemopilema nomurai. Previous reports on its occurrence (Hon et al. 1978, Zhang \& Li 1988, Cheng et al. 2004, Omori \& Kitamura 2004) indicate that the main habitat of this species is in the northern parts of the East China Sea, Yellow Sea and Bohai Sea. This species is also carried by the Tsushima Current to the Sea of Japan, usually in small numbers, but very rarely in extreme abundances (e.g. thousands of 
medusae entrapped per set-net $\mathrm{d}^{-1}$ ) sufficient to seriously damage local fisheries. To our knowledge, such mass occurrences of $N$. nomurai took place in 1920, 1958, 1995 and 2002 (Kishinouye 1922, Nishimura 1959, 1961, Shimomura 1959, Yasuda 2004). The blooms of 2002 and 2003 represent the first time such abundances occurred in 2 consecutive years. $N$. nomurai also bloomed in 2004, but the bloom was not as extensive as during the 2 preceding years. Population explosions of $N$. nomurai appear to have become more frequent and larger in extent over the last decade. A similar phenomenon has also been observed in Korean coastal waters (Dr. Y. S. Kang, National Fisheries Research and Development Institute, pers. comm.). This suggests that environmental and/or ecological changes, resulting from a variety of factors, may be enhancing the jellyfish populations in coastal waters of East Asia, as has already been demonstrated in the Bering Sea (Brodeur et al. 1999, 2002), northern Gulf of Mexico (Graham 2001, Graham et al. 2003) and the Black Sea (Purcell et al. 2001, Shiganova et al. 2001). Furthermore, there have been some earlier reports about invasions by rhizostome species, Rhopilema nomadica (Galil et al. 1990, Lotan et al. 1992, Kideys \& Gücü 1995, Silfen et al. 2003) and Phyllorhiza punctata (Graham et al. 2003). These cases indicate that $N$. nomurai may have the potential to invade and colonise the Sea of Japan.

In order to clarify the causes for the observed mass occurrences of Nemopilema nomurai, it is necessary to understand its life cycle, geographic origins and transportation routes. We succeeded in obtaining fertilized eggs of this species, and followed the development from scyphistoma to young medusa in the laboratory for the first time. In this paper, we report on the mass occurrences of medusae in 2003 and 2004, and describe the morphological and ecological characteristics of various life stages. Based on field and laboratory studies, we construct the seasonal life cycle and geographical range of $N$. nomurai, and speculate on the possible causes for the unusual mass occurrences.

\section{MATERIALS AND METHODS}

Mass occurrences in 2003 and 2004. We collected information on the occurrence of Nemopilema nomurai by: (1) actual visits to the sites and personal interviews with local fishermen and (2) telephone and Email communications with local diving shops and fisheries cooperatives. Having become aware of the mass occurrence of $N$. nomurai, the Japan Sea National Fisheries Research Institute undertook a rapidresponse survey from late August 2003, by requesting fisheries offices of 18 prefectures to report the incidents (e.g. dates, locations, type of fishing nets and approximate numbers of medusae caught per net). From the compiled information for 2003 and 2004 (www.jsnf.affrc.go.jp/), we calculated the average number of medusae entrapped per set-net $\mathrm{d}^{-1}$ for every half-month period for 5 representative prefectures (i.e. Shimane, Kyoto, Niigata, Aomori and Miyagi; see Fig. 1 for locations). These prefectures usually collected information about the incidents from 10 to 30 set-net owners.

Artificial fertilization. We collected mature Nemopilema nomurai during the period between 23 October and 7 November 2003, in Kamo Inlet, a small inlet at Oki Island (Fig. 1). Gonadal fragments (ca. $500 \mathrm{~g}$ ) were cut off and transported to a laboratory at the Oki Marine Biological Station, Shimane University. Small pieces of ovary and testis (ca. $10 \mathrm{~g}$ ) from 3 to 5 specimens were placed together in a plastic colander $(20 \mathrm{~cm}$ in diameter) set up in a plastic funnel, through which the seawater was gently running from a hose to a plankton net with $30 \mu \mathrm{m}$ mesh. Fertilized eggs and planulae were collected in the cod-end of the plankton net. The planulae were isolated with a Pasteur pipette under a dissecting microscope and transferred to styrene vessels containing $300 \mathrm{ml}$ filtered seawater of

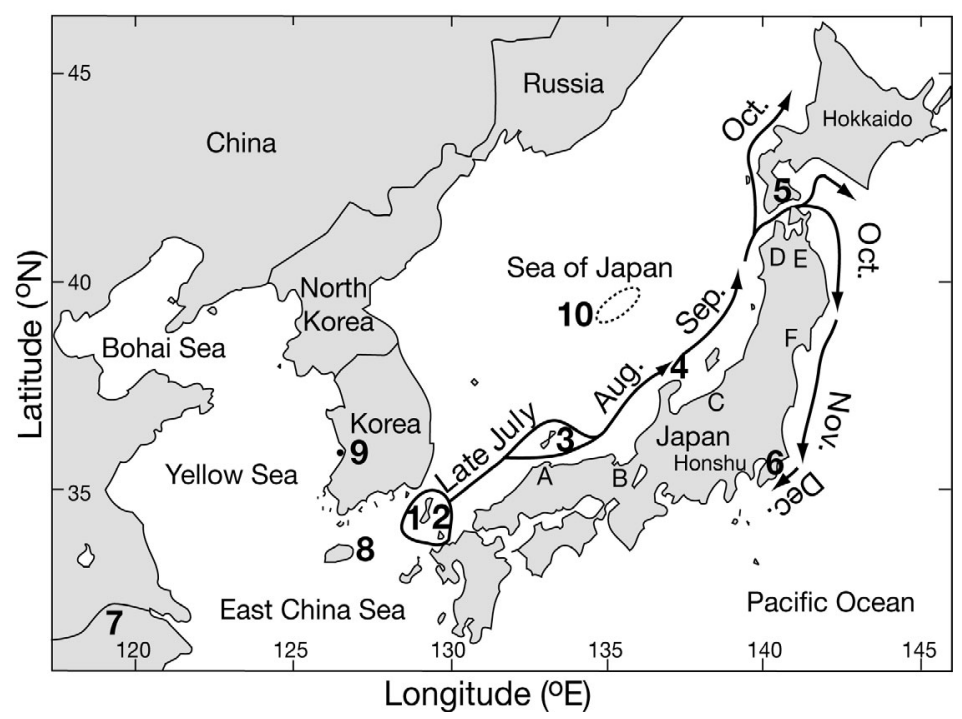

Fig. 1. Nemopilema nomurai. Monthly geographical expansion of the occurrence of $N$. nomurai along the coast of Japan in 2003, based on various information sources (see 'Materials and methods' and 'Results'). 1: Tsushima Island; 2: Iki Island; 3: Oki Island; 4: Noto Peninsula; 5: Tsugaru Strait; 6: Boso Peninsula; 7: Changjiang (Yangtze) River; 8: Cheju Island; 9: Gunsan; 10: Yamato Bank; A: Shimane prefecture (pref); B: Kyoto pref; C: Niigata pref; D: West Aomori pref; E: East Aomori pref; F: Miyagi pref 
$33 \mathrm{psu}$. These procedures were undertaken at ambient temperatures ranging from 18 to $22^{\circ} \mathrm{C}$.

Laboratory rearing. Scyphistomae settling on the bottom of the vessels were fed with copepod nauplii isolated from natural zooplankton samples at least once a day. Scyphistomae ( $7 \mathrm{~d}$ old) were transported to the laboratory of Hiroshima University, HigashiHiroshima, by filling the styrene containers with seawater to make them airtight. After removing the lid, the containers were placed on the bottom of glass aquaria containing $10 \mathrm{l}$ of seawater in a temperature control room $\left(18^{\circ} \mathrm{C}, 12: 12 \mathrm{~h}\right.$ light:dark photoperiodicity), so that most of the scyphistomae were in a suspended position. At 2 to $3 \mathrm{~d}$ intervals newly hatched Artemia nauplii (Vinh Chau, Vietnam) were given as food, and dead Artemia were removed with a pipette. After the scyphistomae were kept for $6 \mathrm{mo}$, they were separated into 2 groups and exposed to 13 and $9^{\circ} \mathrm{C}$, respectively, for 1 mo before being returned to $18^{\circ} \mathrm{C}$ for possible induction of strobilation. Since nothing happened, they were kept at $18^{\circ} \mathrm{C}$ for 1 mo further and again exposed to $13^{\circ} \mathrm{C}$ for 1 mo before delivering a stronger thermal stimulus, i.e. elevating the temperature to $23^{\circ} \mathrm{C}$, to induce strobilation. Shortly thereafter, strobilation began. Ephyrae were reared to young medusae in containers of various volumes from 0.5 to $20 \mathrm{l}$ at temperatures ranging from 22 to $28^{\circ} \mathrm{C}$, with newly hatched Artemia nauplii being used as food at least twice daily. Half of the rearing water was replaced with fresh seawater at $2 \mathrm{~d}$ intervals. The wet weight of each life stage was measured by an electric balance, and selected specimens were preserved in $5 \%$ formalin-seawater solution.

\section{RESULTS}

\section{Mass occurrences in 2003 and 2004}

Nemopilema nomurai first appeared in southern Japan (Tsushima Island) in late July 2003. Local fishermen observed that $<10 \mathrm{~d}^{-1}$ medusae began to enter their set-nets. Continuous reports on the mass occurrence of $N$. nomurai were received from coastal areas all around the Sea of Japan soon after this first sighting (Fig. 1). The medusae at the leading edge of this bloom were transported by the Tsushima Current to near the Noto Peninsula by the end of August. In September, they reached northern Honshu. In October, the population split into 2 groups, one drifting northward along the west coast of Hokkaido and the other passing through the Tsugaru Strait to the Pacific Ocean. The latter was transported by a northerly coastal current along northern Honshu as far south as the Boso Peninsula, until the medusae died in December.
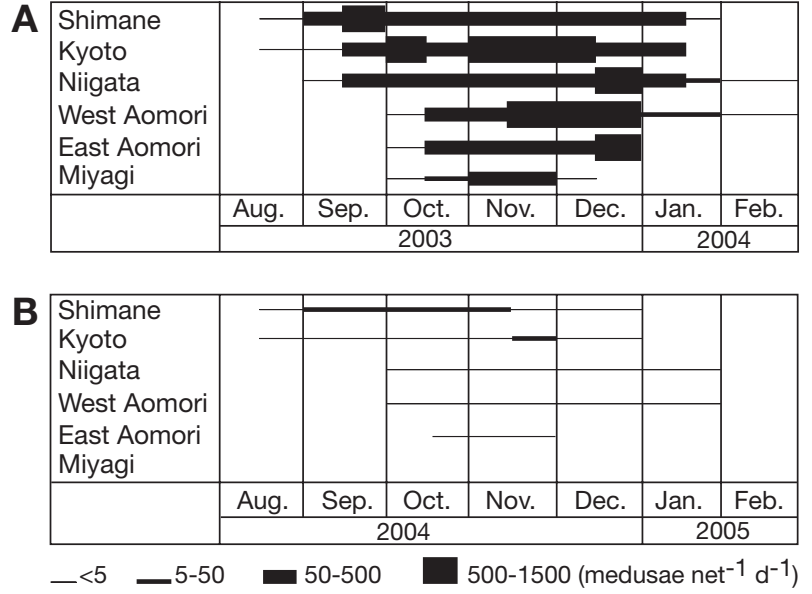

Fig. 2. Nemopilema nomurai. Daily average number of jellyfish caught per set-net in Shimane, Kyoto, Niigata, Aomori (west and east) and Miyagi prefectures in (A) 2003/2004 and (B) 2004/2005. See Fig. 1 for prefecture locations

Temporal changes in average daily medusa abundance caught per set-net in Shimane, Kyoto, Niigata, Aomori (both Sea of Japan and Pacific sides) and Miyagi prefectures in 2003 and 2004 are shown in Fig. 2. At each location, the main bloom population arrived about 1 mo after the first occurrence of the medusae. Entrapment of $>50$ medusae per set-net $\mathrm{d}^{-1}$ continued for 4 to 5 mo in Shimane, Kyoto and Niigata, for $3 \mathrm{mo}$ in Aomori and for $1 \mathrm{mo}$ in Miyagi.

Along the entire coast of the Sea of Japan and on the Pacific side of northern Honshu, the aggregation of Nemopilema nomurai caused severe damage not only to set-net but also to seine-net, gill-net and trawl fisheries, which continued until the medusae died off by midwinter. The problems included: (1) clogging and bursting of the nets, (2) lower catches of finfish, (3) high mortality of finfish by nematocyst venom, and lower commercial value, (4) increased labour to remove medusae from the nets, (5) higher risk of capsizing trawl boats, (6) painful stings caused by medusae etc. One of the most severe incidents was reported by Niu Fisheries Cooperative on the west coast of the Noto Peninsula: several thousand medusae were trapped almost daily in a set-net during October (Fig. 3; Y. Taniguchi pers. comm.). Many set-net fishermen were forced to remove their nets even during the regular fishing season. The nuisance to fisheries created by $N$. nomurai has been reported from at least 17 prefectures (www.jsnf.affrc.go.jp/). Although no information is available on the total loss for all prefectures, the loss (e.g. decrease in fish catch, damage to nets, etc.) in Aomori prefecture alone was 2.3 billion Japanese yen (ca. 20 million US\$)

In 2004, fishermen and researchers were on the alert for a possible repeat of the event. Indeed, Nemopilema nomurai began to occur in the Tsushima and Korea 


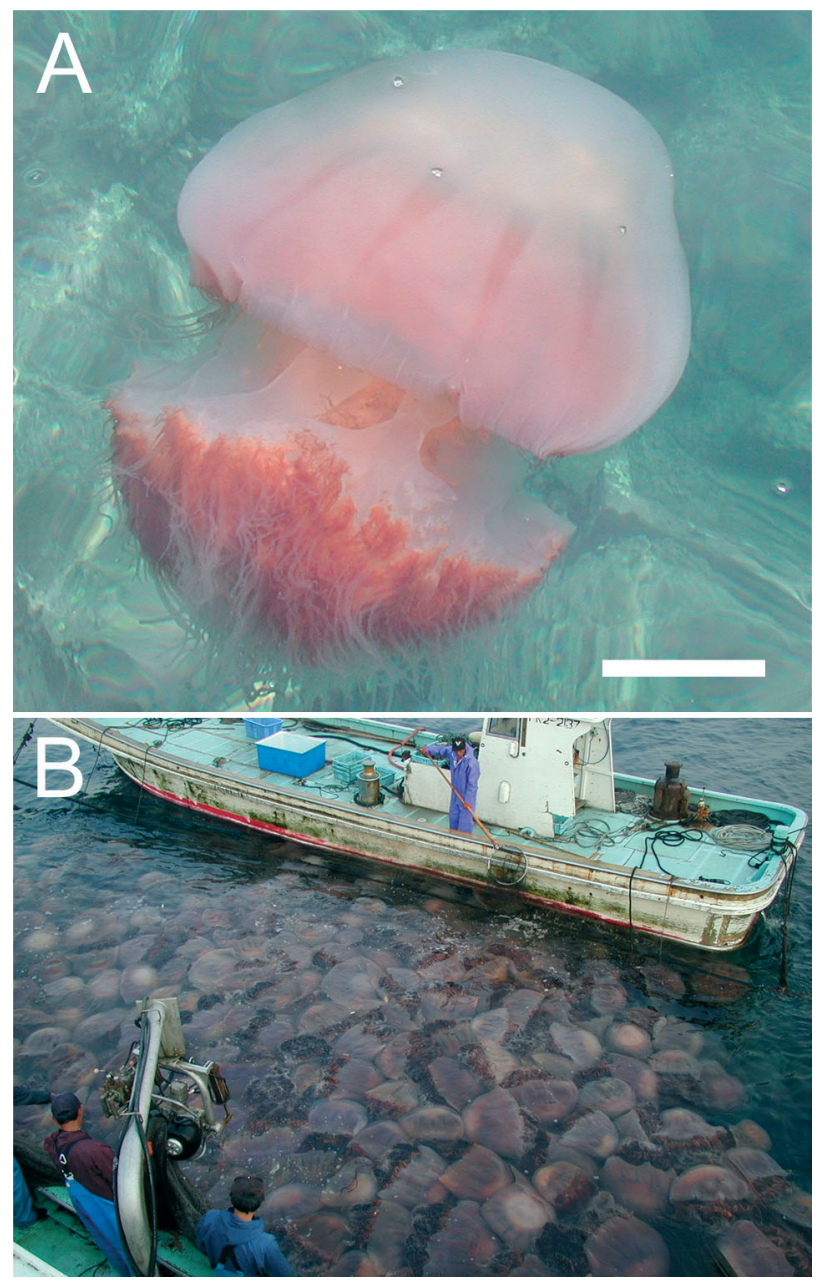

Fig. 3. Nemopilema nomurai. (A) Immature medusa at Tsushima Island in August 2003. (B) Mass occurrence of mature medusae in a set-net on the western coast of the Noto Peninsula (courtesy of Mr. Y. Taniguchi, Niu Fisheries Cooperative). Scale bar $=10 \mathrm{~cm}(\mathrm{~A})$

Strait in August, and followed a distributional pattern similar to that of the previous year. However, the bloom in 2004 was 2 to 3 orders of magnitude less intense than that of the previous year, since the maximum average number of jellyfish trapped was ca. 50 medusae per set-net $\mathrm{d}^{-1}$ (Fig. 2). Prior to transportation to the Sea of Japan, new information on the occurrence of $N$. nomurai was obtained. Several tens of juvenile $N$. nomurai medusae (extended bell diameter: 2 to $8 \mathrm{~cm}$ ) were collected in early June in a set-net near Gunsan, west Korea (Y. S. Kang pers. comm.), and a total of ca. $700 \mathrm{~kg}$ of medusae (extended bell diameter: ca. 50 to $100 \mathrm{~cm}$ ) was caught in the middle of July by a trawl-net (net opening: $5 \times 5 \mathrm{~m}$ ) at a station $\left(31^{\circ} 45^{\prime} \mathrm{N}, 124^{\circ} 50^{\prime} \mathrm{E}\right.$ ) southwest of Cheju Island, Korea (K. Nishiuchi, Seikai National Fisheries Research Institute, pers. comm.; see Fig. 1 for locations).

\section{Life cycle}

\section{Gonad maturation}

Nemopilema nomurai caught in August around Tsushima and Iki Islands (mean extended diameter: $53 \mathrm{~cm}$, mean wet weight: $7.6 \mathrm{~kg}, \mathrm{n}=21$ ) had a translucently whitish body, with pinkish or reddish scapulets and oral arms (Fig. 3), and transparent immature gonads. The medusae caught on the coast of south-western Honshu in mid-September (no size and weight data) still appeared to be immature, due to their transparent gonads. However, those sampled at Oki Island in October (mean extended diameter: $110 \mathrm{~cm}$, mean wet weight: $66.0 \mathrm{~kg}, \mathrm{n}=4$ ) had colored gonads (male testis: milky white; female ovary: dark brown) (Fig. 4A). Of 20 medusae sampled for artificial fertilization, 13 individuals were males and 7 were females. All males had sperm follicles containing mobile spermatozoa (Fig. 4B), indicating that they were fully mature. The ovaries of females contained different-sized oocytes, ranging from 30 to $80 \mu \mathrm{m}$ in diameter. The oocytes of 60 to $80 \mu \mathrm{m}$ diameter had a clear germinal vesicle (Fig. 4C), indicating that oogenesis stopped at the Prophase I stage of meiosis. Neither fertilized eggs nor planulae were found in or on the ovary, which indicates that fertilization takes place in the water. In December, medusae of $N$. nomurai attained maximum size (mean extended diameter: $123 \mathrm{~cm}$, mean wet weight: $96.3 \mathrm{~kg}, \mathrm{n}=4$ ), and the gonads of 20 medusae examined looked the same as in October.

\section{Fertilization and planula}

Fertilized eggs and planulae were taken 2 to $4 \mathrm{~d}$ after the start of incubation in the artificial fertilization apparatus. The fertilized eggs were ca. 60 to $80 \mu \mathrm{m}$ in diameter, with a transparent perivitelline space of ca. $8 \mu \mathrm{m}$ (Fig. 4D). The first and second polar bodies, which were discharged into the perivitelline space, were clearly visible. The fertilized eggs developed into planula larvae about $24 \mathrm{~h}$ after fertilization at $20^{\circ} \mathrm{C}$. Planulae were ca. $170 \mu \mathrm{m}$ long and ca. $130 \mu \mathrm{m}$ wide, whitish in color and covered with cilia or flagella of $10 \mu \mathrm{m}$ length over the body surface (Fig. 4E). They swam for 4 to $8 \mathrm{~d}$ until settlement occurred on the bottom of the styrene vessels. We placed bivalve shells, slide glasses and ceramic plates in the styrene vessels to evaluate substrate preference, but very few planulae settled on these materials. However, many planulae attached to the air-water interface and underwent morphogenesis there. 

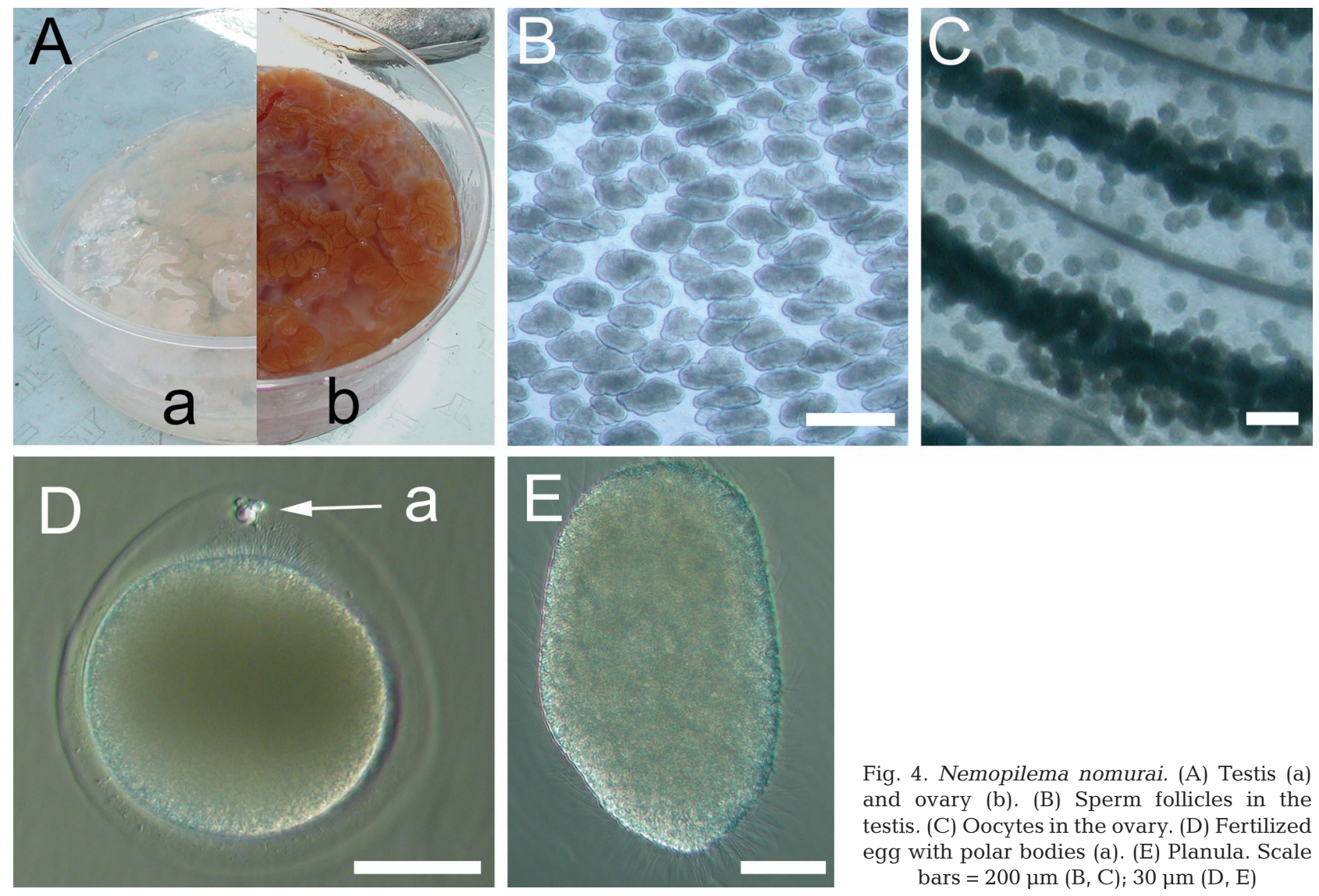

Fig. 4. Nemopilema nomurai. (A) Testis (a) and ovary (b). (B) Sperm follicles in the testis. (C) Oocytes in the ovary. (D) Fertilized egg with polar bodies (a). (E) Planula. Scale bars $=200 \mu \mathrm{m}(\mathrm{B}, \mathrm{C}) ; 30 \mu \mathrm{m}(\mathrm{D}, \mathrm{E})$

\section{Scyphistoma}

Newly settled scyphistomae were translucently whitish, goblet-shaped, and had 4 tentacles. The calyx was 250 to $300 \mu \mathrm{m}$ in diameter. The dome-shaped manubrium was one-third of the scyphistoma height. Immediately after settlement, they were able to ingest copepod nauplii of ca. $40 \mu \mathrm{m}$ body length using their tentacles.

Young scyphistomae developed to an intermediate stage with 8 tentacles 6 to $10 \mathrm{~d}$ after settlement. The calyx diameter was ca. $500 \mu \mathrm{m}$. They were able to ingest newly hatched Artemia nauplii of ca. $300 \mu \mathrm{m}$ body length.

The fully developed scyphistoma stage, with 16 tentacles, was attained 10 to $20 \mathrm{~d}$ after settlement. The calyx diameter was 800 to $1100 \mu \mathrm{m}$. A stolon protruded from the bottom of the calyx and attached to the substrate ca. 10 to $300 \mu \mathrm{m}$ away from the base of the scyphistoma. The scyphistoma body mass gradually moved to the new attachment site, leaving a podocyst behind at the former position. The podocyst was whitish in color and ca. $300 \mu \mathrm{m}$ in diameter (Fig. 5A). From the podocyst, a new scyphistoma was formed. Asexual reproduction by means of podocyst formation was continuous until strobilation. The duration of the formation of a new podocyst varied greatly, from $7 \mathrm{~d}$ to
3 mo. Fig. 5A shows a scyphistoma colony from a single original (or founder) scyphistoma, formed over $6 \mathrm{mo}$ at $18^{\circ} \mathrm{C}$. From a single founder, we observed the generation of as many as 18 podocysts, from which 6 scyphistomae were newly formed. The scyphistomae survived at $9^{\circ} \mathrm{C}$ for at least 1 mo.

\section{Strobila}

Within $24 \mathrm{~h}$ of a temperature increase from 13 to $23^{\circ} \mathrm{C}$, strobilation was induced; the calyx became elongated and segmented. The regression of tentacles started about $30 \mathrm{~h}$ after the beginning of strobilation; following the start of regression, rhopalia with statoliths became apparent. Both ephyral lappets and manubrium elongated, and simultaneously the tentacles of the basal scyphistoma regressed. Nascent ephyrae pulsated rhythmically, and the tip of the manubrium turned brown in color $48 \mathrm{~h}$ after strobilation began (Fig. 5B). Fully developed strobilae, 2.2 to $2.8 \mathrm{~mm}$ long from the base of the scyphistoma to the top of the ephyral mouth, liberated ephyrae one by one into the water within $7 \mathrm{~d}$ after strobilation. The numbers of ephyrae formed by a strobila varied from 3 to 7 (mean: $4.6, \mathrm{n}=16$ ). 

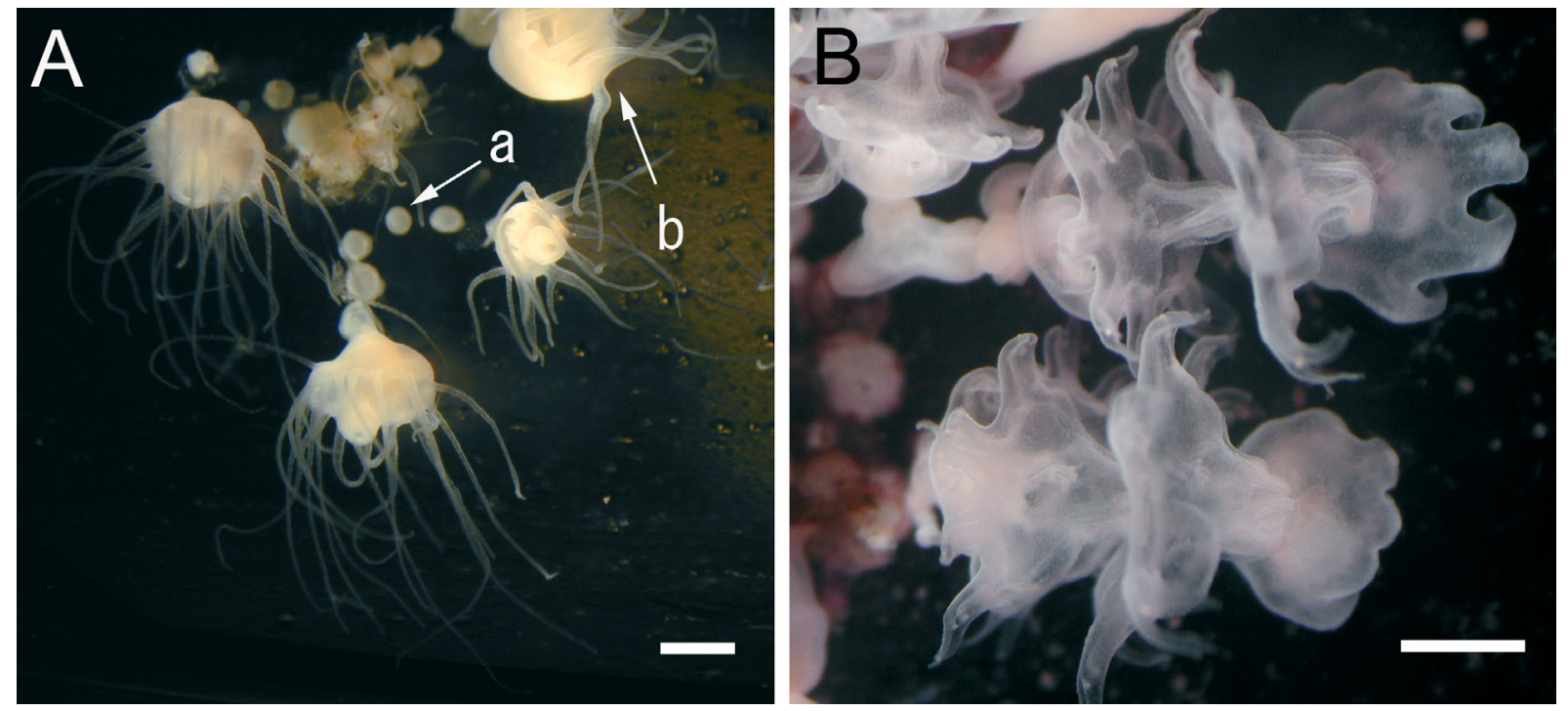

Fig. 5. Nemopilema nomurai. (A) A colony of scyphistomae and podocysts (a) formed from a founder scyphistoma (b). (B) $48 \mathrm{~h}$ old strobilae. Scale bars $=1 \mathrm{~mm}$

Ephyra

Newly liberated ephyrae were 2.2 to $3.8 \mathrm{~mm}$ wide from lappet tip to lappet tip (Fig. 6A). There were 8 pairs of lappets and 8 rhopalia. The rhopalar clefts were usually U-shaped and reached more than onethird of the distance along the marginal lobe. The distal end of each lappet branched into 2 to 6 pointed tips. Nematocyst batteries were present, particularly in the centre and along radial canals of the exumbrella. The ephyra was able to ingest Artemia nauplii immediately after liberation.

As the ephyrae grew to ca. $8 \mathrm{~mm}$ wide from lappet tip to lappet tip (i.e. $5 \mathrm{~d}$ post-liberation), 8 pairs of secondary lappets developed, extending approximately to onethird of the length of the primary lappets at the mid-point of each cleft (Fig. 6B). The 4 oral arms changed to become J-shaped in lateral view, and each branched into 2 terminally. At the same time, the subgenital cavity and the primitive scapulets appeared (Fig. 6C).

\section{Metephyra}

The ephyrae grew to metephyrae, reaching a width of 8 to $14 \mathrm{~mm}$ from lappet tip to lappet tip ca. $10 \mathrm{~d}$ postliberation (Fig. 6D). The secondary lappets extended outwards to the primary lappets, making the bell margin polygonal. A ring canal appeared along the bell margin and connected with the 16 radial canals. The oral arms were clearly divided into 8 , and each arm branched into 2 wings at the tip. The distal half of each scapulet branched into 2 wings, and on the upper side of each one, a mouth connected to the scapulet canal opened (Fig. 6E). Nematocyst batteries were scattered over the entire exumbrella.

In advanced metephyrae (up to 14 to $18 \mathrm{~mm}$ wide, ca. 20 d post-liberation, Fig. 6 F), 16 centripetal canals extended from the mid-point of the adjacent radial canals on the ring canal (Fig. 6D). The margins of the oral arms and scapulets formed thin membranes, which were folded alternately and complexly as frills carrying numerous cirri (Fig. 6G). Each cirrus bore a small terminal knob armed with nematocysts. The central mouth was still open. At the junction point of the wings where the mouth membranes coalesced, a primary appendage occurred (Fig. 6H). The appendage was: (1) reddish purple, (2) filiform and of 200 to $400 \mu \mathrm{m}$ width, (3) hollow inside, (4) armed with 1 to 5 nematocyst batteries of 140 to $160 \mu \mathrm{m}$ diameter length per mm (Fig. 6I), (5) non-contractile, (6) lacking in predation capacity and (7) elongate, extending about 10 times longer than the body length.

Secondary appendages occurred on the distal ends of each wing (Fig. 6H), followed by the formation of tertiary appendages when new wings were formed about $30 \mathrm{~d}$ post-liberation. Almost at the same time, numerous appendages occurred on the inner oral arms, and the mouth membranes coalesced to form many mouthlets. The radial canals branched out to form many short canals anastomosing like the mesh of a net.

\section{Young medusa}

As the central mouth closed, the metephyra passed into the medusa stage, where they measured 40 to $110 \mathrm{~mm}$ in bell diameter 40 to $50 \mathrm{~d}$ post-liberation 

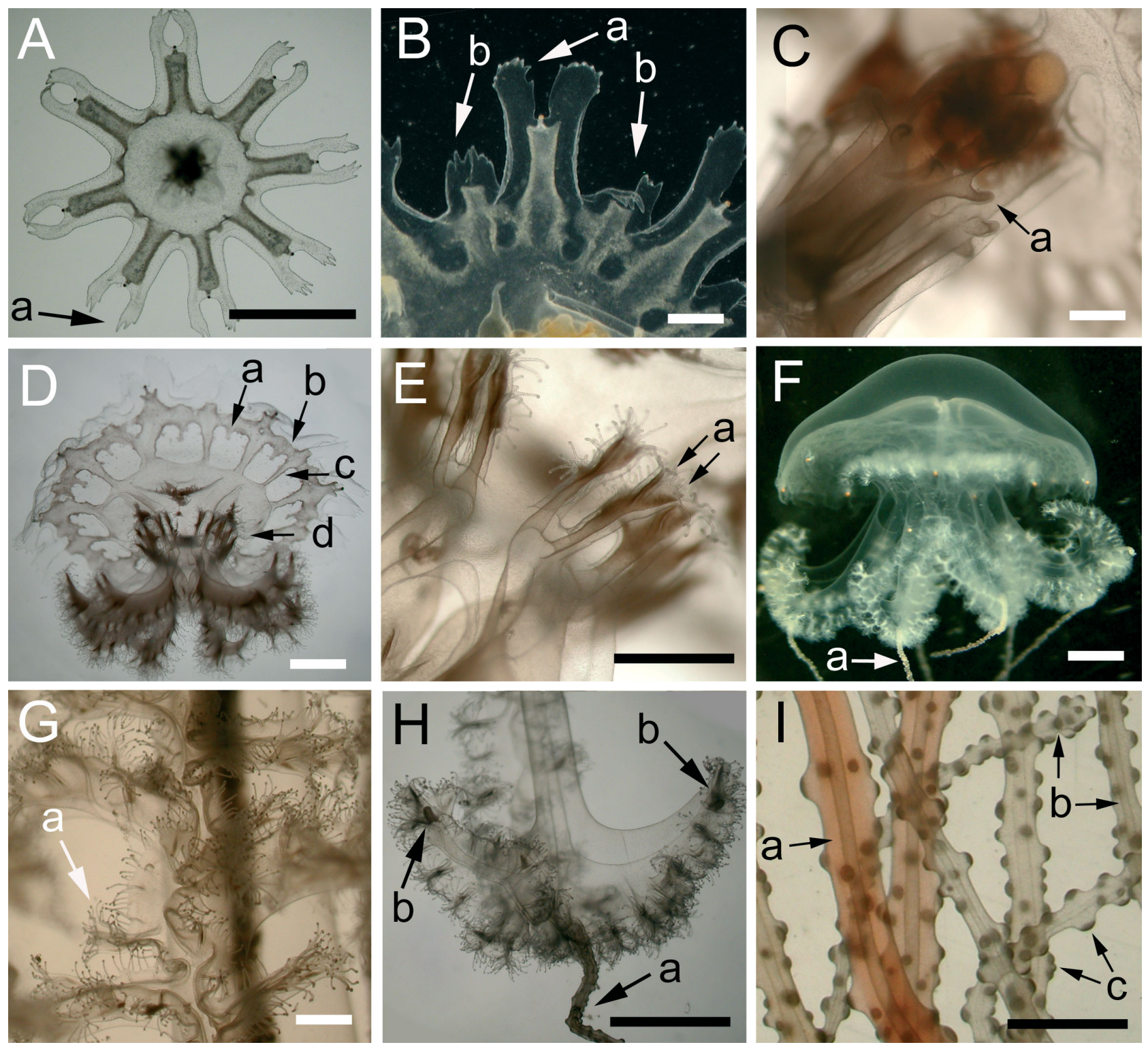

Fig. 6. Nemopilema nomurai. (A) Newly liberated ephyra with pointed lappet tips (a). (B) Advanced ephyra with primary (a) and secondary (b) lappets. (C) Advanced ephyra with primitive scapulets (a). (D) Metephyra with centripetal canals (a) extending from the mid-point of the adjacent radial canals (b) on the ring canal (c) and scapulets (d). (E) Metephyra with scapulets with branched wings (a). (F) Advanced metephyra with primary appendages (a). (G) Mouth membrane of metephyra, with cirri (a). $(\mathrm{H})$ Oral wings of metephyra, with primary (a) and secondary appendages (b). (I) Primary (a) and secondary appendages (b) of metephyra, with nematocyst batteries (c). Scale bars $=1 \mathrm{~mm}(\mathrm{~A}, \mathrm{I}) ; 500 \mu \mathrm{m}(\mathrm{B}, \mathrm{C}, \mathrm{G}) ; 2 \mathrm{~mm}(\mathrm{D}, \mathrm{E}, \mathrm{H}) ; 4 \mathrm{~mm}(\mathrm{~F})$

(Fig. 7A). The lappet tips were light brown in color. The mouth membranes on the oral wings and scapulets coalesced between the mouth canal and distal end of mouthlets. The coalesced parts were gradually penetrated to open as windows with a diameter of 100 to $500 \mu \mathrm{m}$ (Fig. 7B). With the formation of the windows and appendages, the mouth canals became narrower and many mouthlets were formed. Numerous appendages occurred on the oral wings and scapulets. The anastomosing canal network was connected with the gastric cavity only by radial canals (Fig. 7C), a characteristic feature in the suborder Daktyliophorae (Russell 1970, Mianzan \& Cornelius 1999).

\section{Growth}

Mean wet weight of a $20 \mathrm{~d}$ old metephyra (mean extended diameter: $26 \mathrm{~mm}, \mathrm{n}=11$ ) was $1.5 \mathrm{~g}$ and that of a $48 \mathrm{~d}$ old medusa (mean extended diameter: $71 \mathrm{~mm}$, 

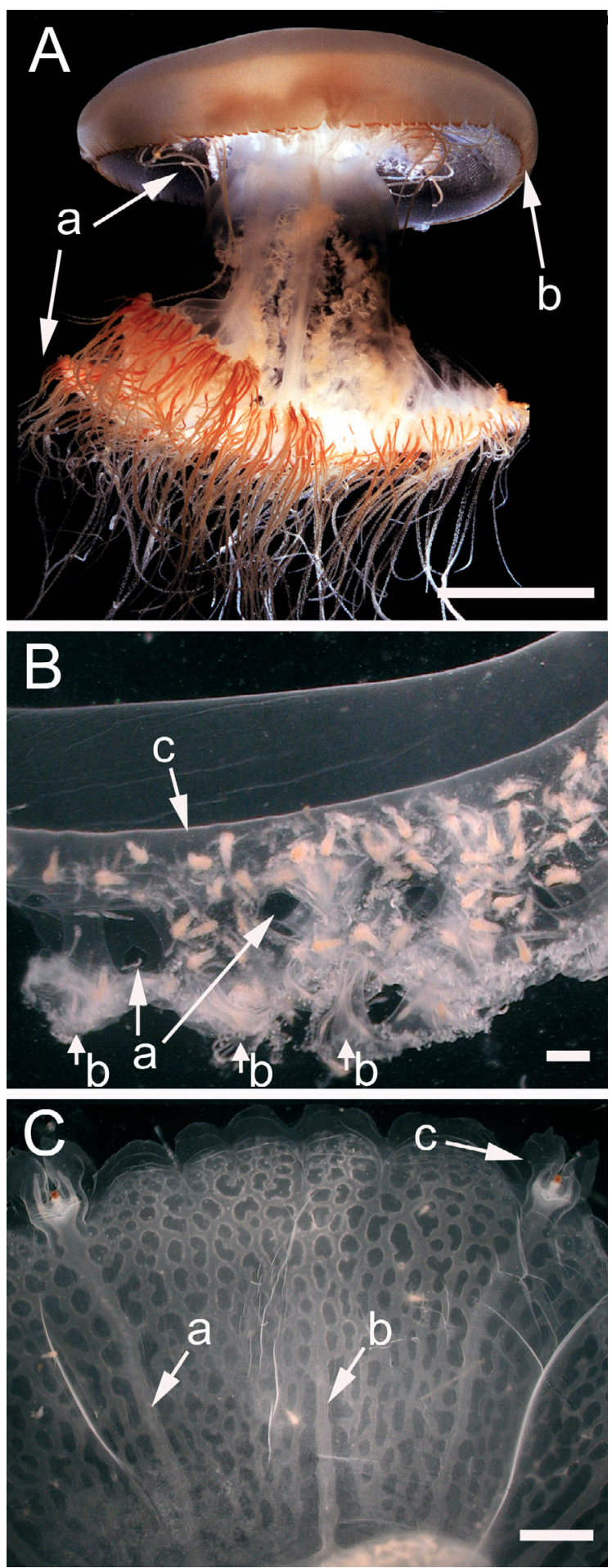

Fig. 7. Nemopilema nomurai. (A) 40 to $50 \mathrm{~d}$ old medusa with appendages (a) and light brown coloured lappets (b) (courtesy of Mr. T. Murakami, Kamo Municipal Aquarium). (B) Oral wing of young medusa, with window-like openings (a) and mouthlets (b). Ingested Artemia nauplii being transported from mouthlets to stomach cavity through the mouth canal (c). (C) Canal system of young medusa, with rhopalar canal (a), inter-rhopalar canal (b) and rhopalium (c). Scale bars $=50 \mathrm{~mm}(\mathrm{~A}) ; 300 \mu \mathrm{m}(\mathrm{B}) ; 4 \mathrm{~mm}(\mathrm{C})$
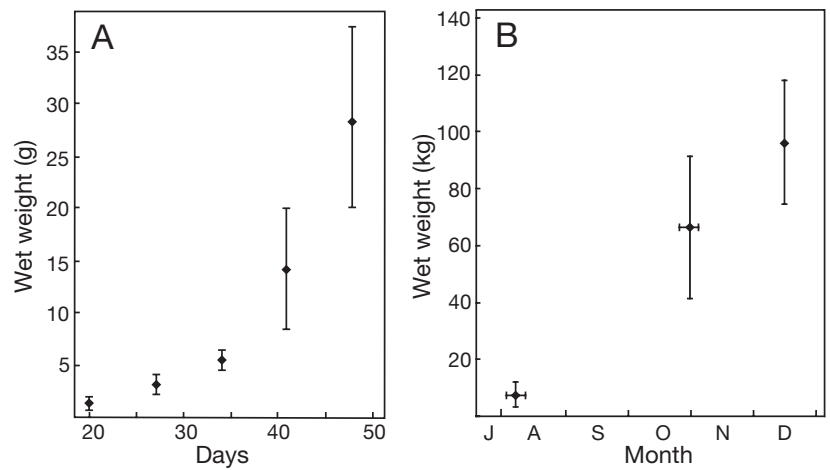

Fig. 8. Nemopilema nomurai. Growth in the (A) laboratory and (B) field. Vertical lines denote standard deviation, and horizontal lines, sampling period

$\mathrm{n}=8$ ) was $29.0 \mathrm{~g}$, showing an exponential growth rate (Fig. 8A). The daily specific growth rate during the above-mentioned period was $0.11 \mathrm{~d}^{-1}$.

The actual measurements of wet weight of wild medusae were sporadic and confined to early August at Tsushima and Iki Islands (mean wet weight: $7.6 \mathrm{~kg}$, $\mathrm{n}=21)$, late October at Oki Island $(66.0 \mathrm{~kg}, \mathrm{n}=3)$ and mid-December at Oki Island (96.3 kg, $\mathrm{n}=4$ ) (Fig. 8B). The specific growth rate between August and December was estimated to be $0.02 \mathrm{~d}^{-1}$.

\section{DISCUSSION}

\section{Mass occurrence}

The temporal shift in the geographical distribution of the Nemopilema nomurai aggregation in 2003 and 2004 was almost the same as in the past, i.e. in 1958, 1995 and 2002 (Nishimura 1959, 1961, Shimomura 1959, Yasuda 2004). Nevertheless, it is unprecedented that the remarkable bloom of $N$. nomurai appeared $3 \mathrm{yr}$ in a row. In the above-mentioned years, the medusae first began to occur in the Tsushima and Korea Strait in mid-summer and then spread into the northern Sea of Japan. Shimomura (1959) investigated the geographical distribution of $N$. nomurai extensively over a wide area of the Sea of Japan in September and October 1958, and found very dense populations (e.g. a medusa every few meters) in the frontal eddies formed by the third branch of the Tsushima Current (Naganuma 1973) in the central Sea of Japan near the Yamato Bank (see Fig. 1 for location). This means that after passage through the Tsushima and Korea Strait, the medusae are transported not only by the first, or the most nearshore, branch of the Tsushima Current, but also to offshore waters by the second and third branches. Although our survey in 2003 and 2004 was primarily confined to coastal waters, offshore popula- 
tions may have been transported to nearshore areas by the wind-driven surface current, as the northwest monsoon prevailed in fall and winter. Congregations of nearshore and offshore populations caused massive aggregations of medusae in set-nets along the coast of the Sea of Japan during these seasons. The majority of medusae died off by mid-winter, probably due to low water temperatures (i.e. ca. $10^{\circ} \mathrm{C}$ ), starvation (Lucas \& Lawes 1998), or simply genetically determined senescence (Möller 1980, Lucas 2001). A very small number of medusae survived until March.

\section{Life cycle and morphological specificity}

From our laboratory-rearing experiments, the life cycle of Nemopilema nomurai was elucidated and is schematically shown in Fig. 9. Its life cycle is essentially the same as that reported for several other rhizostome species (Paspaleff 1938, Calder 1973, 1982, Ding \& Chen 1981, Lotan et al. 1992). The scyphistomae of
$N$. nomurai underwent ongoing asexual reproduction for $>1.5 \mathrm{yr}$ in our laboratory. Our experiments also revealed that thermal elevation, although unnaturally sudden (i.e. a $10^{\circ} \mathrm{C}$ rise over a few hours), is one of the triggers inducing strobilation, as already reported for rhizostome species such as Cephea cephea (Sugiura 1966), Rhopilema esculentum (Chen \& Ding 1983) and $R$. nomadica (Lotan et al. 1994). More detailed studies of temperature effects, mimicking the seasonal thermal increase in nature, are needed to estimate the time of strobilation in the field.

Some morphological and ecological characteristics of Nemopilema nomurai have been compared with closely associated species belonging to the superfamily Scapulatae (Russell 1970, Mianzan \& Cornelius 1999), which includes the genera Nemopilema, Rhizostoma, Rhopilema and Stomolophus (Table 1). Their scyphistoma morphology and methods of asexual reproduction are the same. However, asexual reproduction in Rhizostoma pulmo occurs by polyp budding, stolon budding and planuloid formation, as well as by

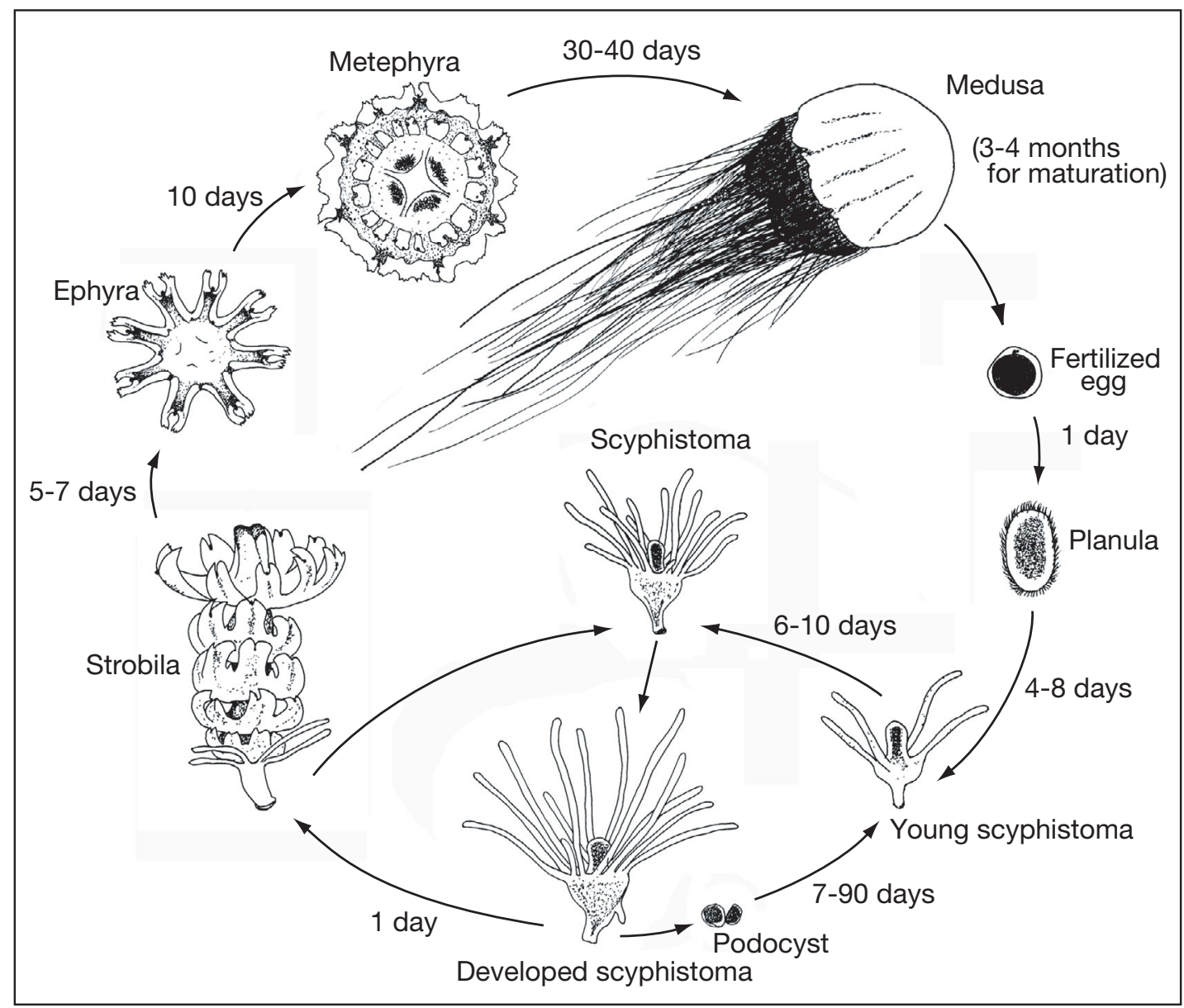

Fig. 9. Nemopilema nomurai. Composite image of the life cycle of $N$. nomurai, based on laboratory and field surveys. Inter-stage durations are also shown 
Table 1. Life cycles and morphology of 6 species of rhizostome Scyphozoa

\begin{tabular}{|c|c|c|c|c|c|c|}
\hline Species & $\begin{array}{c}\text { No. of } \\
\text { tentacles in } \\
\text { scyphistoma }\end{array}$ & $\begin{array}{c}\text { Form of } \\
\text { asexual } \\
\text { reproduction }\end{array}$ & $\begin{array}{c}\text { No. of } \\
\text { ephyrae } \\
\text { per strobila }\end{array}$ & $\begin{array}{l}\text { Morphology of } \\
\text { ephyral lappet }\end{array}$ & $\begin{array}{l}\text { Shape of } \\
\text { appendage }\end{array}$ & Source \\
\hline Nemopilema nomurai & 16 & Podocyst & $3-7$ & $\begin{array}{c}\text { Branched into } 2-6 \\
\text { small tips }\end{array}$ & Filiform & Present study \\
\hline Rhizostoma pulmo & 16 & $\begin{array}{l}\text { Podocyst, } \\
\text { planuloid, } \\
\text { polyp bud, } \\
\text { stolon bud }\end{array}$ & Several & Almost round & $\begin{array}{l}\text { Club-shaped, } \\
\text { triangular in } \\
\text { cross section }\end{array}$ & $\begin{array}{l}\text { Paspaleff (1938), } \\
\text { Russell (1970) }\end{array}$ \\
\hline Rhopilema esculentum & 16 & Podocyst & $6-17$ & $\begin{array}{l}\text { Branched into } \\
4-6 \text { small tips }\end{array}$ & Circular cone & Ding \& Chen (1981) \\
\hline Rhopilema nomadica & 16 & Podocyst & $5-6$ & Almost round & Filiform & $\begin{array}{l}\text { Galil \& Ferguson (1990), } \\
\text { Lotan et al. (1992) }\end{array}$ \\
\hline Rhopilema verrilli & 16 & Podocyst & $\begin{array}{l}1 \text { (occasion- } \\
\text { ally several) }\end{array}$ & Almost round & Circular cone & $\begin{array}{l}\text { Calder (1973), } \\
\text { Kramp (1961) }\end{array}$ \\
\hline Stomolophus meleagris & 16 & Podocyst & $1-3$ & Almost round & Absent & $\begin{array}{l}\text { Calder (1982), Mianzan } \\
\& \text { Cornelius (1999) }\end{array}$ \\
\hline
\end{tabular}

podocysts. The numbers of ephyrae budding from a strobila vary among species, with Rhopilema verrilli usually liberating 1 (i.e. monodisk strobilation) and the others usually liberating $>2$ (i.e. polydisk strobilation). Two groups can be recognised based on the morphology of the ephyral lappets: one group (comprising N. nomurai and Rhopilema esculentum) has 2 to 6 branched tips and another group (comprising Rhizostoma pulmo, Rhopilema nomadica, $R$. verrilli and Stomolophus meleagris) has almost round tips. This means that the ephyrae of $N$. nomurai and $R$. esculentum, which usually co-occur in Chinese coastal waters (Hon et al. 1978, Chen \& Lu 1991), cannot be morphologically distinguished based on this character. However, their metephyrae and young medusae can be differentiated by the shape of the appendages; $N$. nomurai, like $R$. nomadica, bears numerous long and filiform appendages, while $R$. esculentum, like $R$. verrilli and $R$. pulmo, bears fusiform appendages (Kramp 1961, Russell 1970, Omori \& Kitamura 2004). S. meleagris has no appendages (Mianzan \& Cornelius 1999).

\section{Seasonal life cycle and geographical distribution in East Asian waters}

As shown in Fig. 1, the distribution of Nemopilema nomurai is clearly confined to the Tsushima Current and regions influenced by it, such as the Pacific side of Honshu, where the medusae are like live drifting bottles. In the Sea of Japan, young $N$. nomurai with bell diameters $<30 \mathrm{~cm}$ have never been reported; $N$. nomurai with bell diameters $>30 \mathrm{~cm}$ began to appear from late July. The locations where scyphistomae exist and where ephyrae and medusae originate are unknown, but it is speculated that they are from coastal areas along China and the western Korean Peninsula (i.e. the Bohai, Yellow and northern East China Seas), because mature medusae are often found in great numbers and are commercially harvested in these areas (Hon et al. 1978, Omori 1978, Zhang \& Li 1988, Cheng et al. 2004, Omori \& Kitamura 2004).

The results of our laboratory and field surveys are combined to construct the seasonal life cycle and associated geographical distribution of Nemopilema nomurai in East Asian waters. The growth rate of laboratory-reared $N$. nomurai fed on Artemia nauplii was $0.11 \mathrm{~d}^{-1}$, although an even higher growth rate might be expected if medusae were reared in more spacious aquaria. Extrapolating this growth rate to the field population of medusae weighing $7.6 \mathrm{~kg}$, which is the mean wet weight in early August, an estimated $99 \mathrm{~d}$ would be required to attain this size following the liberation of the ephyra. Thus, we estimate that the liberation of ephyrae occurred in early May. Taking variable environmental conditions in the field into account, we speculate that strobilation and ephyral liberation may take place in April, May and June, when water temperature increases from ca. 10 to $20^{\circ} \mathrm{C}$, coinciding with the rise that triggered strobilation in the laboratory, as depicted in Fig. 10. This speculation is also supported by findings of juvenile medusae (we examined their morphology and confirmed that they are N. nomurai) in early June 2004, in Gunsan, west Korea, where ephyrae might be liberated in late April and early May based on our estimate of the growth.

Only a few reports are available on the occurrence of Nemopilema nomurai in June and July. A local set-net fisherman at Cheju Island informed us during an interview that $N$. nomurai, measuring 20 to $30 \mathrm{~cm}$ in bell diameter, began to appear in 2003 during June. Another 


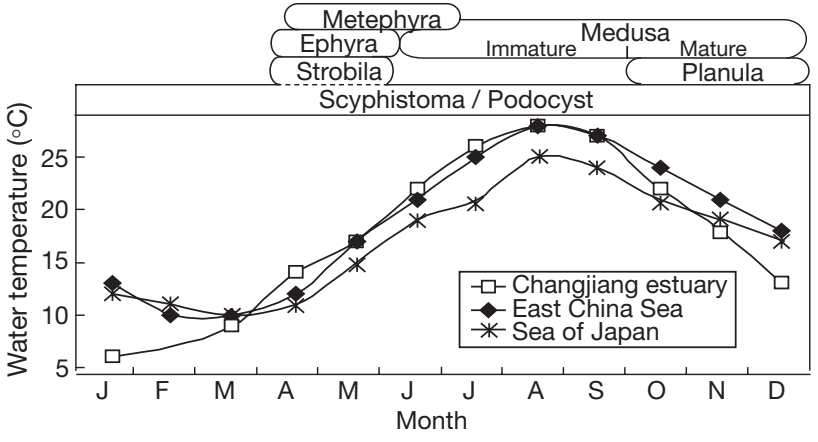

Fig. 10. Nemopilema nomurai. Estimated seasonal life cycle in East Asian waters. Monthly average surface water temperatures in the Changjiang estuary $\left(122^{\circ} \mathrm{N}, 31^{\circ} \mathrm{E}\right)$, East China Sea $\left(125^{\circ} \mathrm{N}, 31^{\circ} \mathrm{E}\right)$ and southern Sea of Japan $\left(134^{\circ} \mathrm{N}, 36^{\circ} \mathrm{E}\right)$ in 2003 are also shown (satellite images provided by the Japan Meteorological Agency)

report concerns the catch of a large number of 50 to $100 \mathrm{~cm}$ diameter medusae by RV 'Youkou Maru' (Seikai National Fisheries Research Institute) southwest of Cheju Island in mid-July 2004. June and July coincide with the rainy season in temperate East Asia. An increased freshwater discharge from the Changjiang (Yangtze) River forms a low salinity water mass in the southern Yellow Sea and northern East China Sea, which extends north-eastwards toward Cheju Island (our Fig. 11, Chang \& Isobe 2003). It is highly likely that larval and young medusae originating from the coastal waters of China and Korea are trapped in

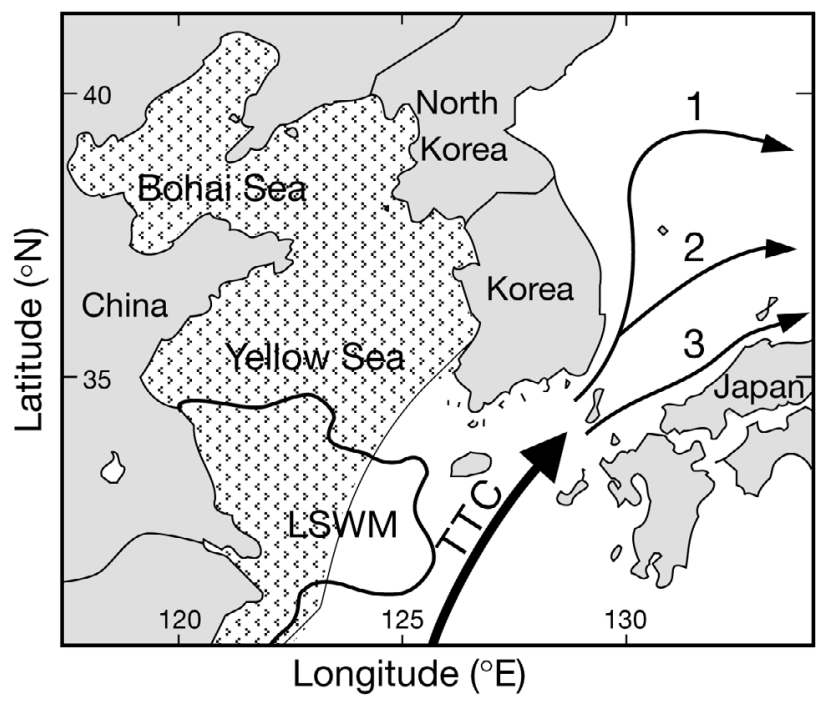

Fig. 11. Schematic representation of hydrographical features in early summer in East Asian waters, which may play a role in the transportation of Nemopilema nomurai medusae from their expected seeding place (dotted area) to the Sea of Japan. LSWM: low salinity ( $<30$ psu) water mass (from Chang \& Isobe 2003); TTC: Taiwan-Tsushima Current (from Isobe 1999); 1, 2, 3: first, second and third branch of the Tsushima Current (from Naganuma 1973) this water mass and then entrained by the southerly Taiwan-Tsushima Current (Isobe 1999), as schematically shown in Fig. 11. The main population of N. nomurai resides in the Bohai, Yellow and northern East China Seas, while a sub-population extending from the main habitat is transported into the Sea of Japan.

Medusae grow at relatively higher rates in summer, when water temperatures rise to $>25^{\circ} \mathrm{C}$, and at much lower rates in fall. The medusae were mature by October. So far, we have observed no evidence of natural spawning and/or sperm release of Nemopilema nomurai in the field, even in aggregated conditions in the setnets. In the main habitat, we presume that maturation and sexual reproduction occur in the fall. Resulting planulae settle on suitable substrates and give rise to scyphistomae, which undergo quasi-perennial asexual reproduction, making this area a seedbed (Figs. 10 \& 11).

\section{Possible causes of mass occurrences and future prospects}

Why blooms of expatriated medusae occurred and why the blooms were infrequent in the past (once every several decades), but have become more frequent in the last decade, are still open questions. Tanaka \& Suzuki (2005) found that blooms occurred 3 to $4 \mathrm{yr}$ after heavy flooding in the Changjiang River plain, but gave no plausible explanation for a link between heavy rain and jellyfish blooms 3 to 4 yr later. It has been argued that environmental changes, such as increased eutrophication, habitat modification, overfishing and global warming, may be responsible for the enhancement of jellyfish populations (Arai 2001, Graham 2001, Parsons \& Lalli 2002, Uye \& Ueta 2004). Indeed, such environmental changes are significant in Chinese coastal waters (Zhang et al. 1999, Anderson et al. 2002, Li et al. 2002). Hence, we speculate that both recent ecosystem change and annual hydrographical conditions (e.g. Changjiang River discharge, expansion of low salinity water mass, strength of the Taiwan-Tsushima Current) in and near the main habitat of Nemopilema nomurai may be responsible for the frequent bloom occurrence in the Sea of Japan.

There have been some earlier reports about invasions by rhizostome species; Rhopilema nomadica, native to the Indo-Pacific region, has invaded the Mediterranean Sea (Galil et al. 1990, Lotan et al. 1992, Kideys \& Gücü 1995, Silfen et al. 2003), and Phyllorhiza punctata, native to Australian waters, has been introduced to the Atlantic (Graham et al. 2003). Given the opportunistic nature of jellyfishes, Nemopilema nomurai has the potential to be successful as an invader in the Sea of Japan. In our experiments, the scyphistomae of $N$. nomurai were kept at $9^{\circ} \mathrm{C}$ for $1 \mathrm{mo}$. Under such conditions, tentacle movements became slower and rates of 
feeding and podocyst formation decreased, but the jellyfish nevertheless survived. Thus, we conclude that the scyphistomae of $N$. nomurai are capable of withstanding the winter season in the southern Sea of Japan, as the annual lowest temperature here is ca. $10^{\circ} \mathrm{C}$ (Fig. 10). Podocysts are essentially dormant stages (Calder 1974, Black 1981), and may be the key to winter survival in much colder waters, such as the Changjiang estuary $\left(5^{\circ} \mathrm{C}\right.$, Fig. 10$)$ and the northern Sea of Japan. Once unfavorable conditions such as low temperatures pass, podocysts 'excyst' and form scyphistomae, which re-establish the population. However, we have no indication whether the invasion is permanent or whether $N$. nomurai undergoes a complete life cycle in the Sea of Japan. If the sessile life stages become established in the Sea of Japan, the bloom of N. nomurai will be an annual event and fisheries might suffer disaster. The risk of this is now considered high.

We have described herein the life cycle and morphological and ecological characteristics of various life stages of Nemopilema nomurai. Such information is essential if the causes of blooms of the species and the impacts these have on both fisheries and food-web dynamics are to be understood. Given the environmental changes occurring in the coastal waters of East Asia, a potential threat exists that population explosions of jellyfishes may increase. Fundamental knowledge provided here may be useful in future investigations of $N$. nomurai, as well as in studies of other jellyfish species (Aurelia aurita, Chrysaora melanaster, Cyanea nozakii, etc.) that tend to explode in abundance periodically in this area.

Acknowledgements. We thank Dr. D. R. Calder and Dr. H. W. Mianzan for their critical reading and stimulating comments. Among the many people who provided support and help in our samplings and data collection, we especially thank Messrs. O. Yamakawa, Y. Sakumoto and S. Kurotaki, captains and set-net owners. Dr. Y. S. Kang and Mr. B. Y. Kim helped in our survey at Cheju Island. Jellyfish photographs were provided courtesy of Messrs. Y. Taniguchi and T. Murakami. We also thank Mr. M. Aoyama and Ms. M. Hayashi, Hiroshima University, for their aid in samplings and rearing experiments. This study was partially supported by research grants from the Japan Science Promotion Society (No. 16405001) and by a research project for utilizing advanced technologies in agriculture, forestry and fisheries from the Agriculture, Forestry and Fisheries Research Council.

\section{LITERATURE CITED}

Anderson DM, Glibert PM, Burkholder JM (2002) Harmful algal blooms and eutrophication: nutrient sources, composition, and consequences. Estuaries 25:704-726

Arai MN (2001) Pelagic coelenterates and eutrophication: a review. Hydrobiologia 451:69-87

Black RE (1981) Metabolism and ultrastructure of dormant podocysts of Chrysaora quinquecirrha (Scyphozoa). J Exp Zool 218:175-182
Brodeur RD, Mills CE, Overland JE, Walters GE, Schumacher $\mathrm{J}$ (1999) Evidence for a substantial increase in gelatinous zooplankton in the Bering Sea, with possible links to climate change. Fish Oceanogr 8:296-306

Brodeur RD, Sugisaki H, Hunt GL (2002) Increases in jellyfish biomass in the Bering Sea: implications for the ecosystem. Mar Ecol Prog Ser 233:89-104

Calder DR (1973) Laboratory observations on the life history of Rhopilema verrilli (Scyphozoa: Rhizostomeae). Mar Biol 21:109-114

Calder DR (1974) Strobilation of the sea nettle, Chrysaora quinquecirrha, under field conditions. Biol Bull (Woods Hole) 146:326-334

Calder DR (1982) Life history of the cannonball jellyfish, Stomolophus meleagris L. Agassiz, 1860 (Scyphozoa, Rhizostomida). Biol Bull (Woods Hole) 162:149-162

Chang PH, Isobe A (2003) A numerical study on the Changjiang diluted water in the Yellow and East China Seas. J Geophys Res C 108:3299

Chen J, Ding G (1983) Effect of temperature on the strobilation of edible medusa, (Rhopilema esculenta Kishinouye Scyphozoa, Rhizostomeae). Acta Zool Sin 29:195-206 (in Chinese with English Abstract)

Chen J, Lu N (1991) Edible medusa. In: Deng J, Zhao C (eds) Ocean fisheries and biology. Agricultural Press of China, Beijing, p 613-640 (in Chinese)

Cheng J, Li S, Ding F, Yan L (2004) Primary analysis on the jellyfish blooms and its cause in the East China Sea and the Yellow Sea. Mod Fish Inf (East China Sea Fisheries Research Institute) 19:10-12 (in Chinese)

Ding G, Chen J (1981) The life history of Rhopilema esculenta Kishinouye. J Fish China 5:93-101 (in Chinese with English abstract)

Galil BS, Spanier E, Ferguson WW (1990) The Scyphomedusae of the Mediterranean coast of Israel, including two lessepsian migrants new to the Mediterranean. Zool Meded 64:95-105

Graham WM (2001) Numerical increases and distributional shifts of Chrysaora quinquecirrha Desor and Aurelia aurita Linne (Cnidaria Scyphozoa) in the northern Gulf of Mexico. Hydrobiologia 451:97-111

Graham WM, Martin DL, Felder DL, Asper VL, Perry HM (2003) Ecological and economic implications of a tropical jellyfish invader in the Gulf of Mexico. Biol Invasions 5: 53-69

Hon H, Chang S, Wang C (1978) Edible medusa (Rhopilema esculentum). Science Press, Beijing, p 1-70 (in Chinese)

Isobe A (1999) On the origin of the Tsushima Warm Current and its seasonality. Contin Shelf Res 19:117-133

Kideys AE, Gücü AC (1995) Rhopilema nomadica: a poisonous Indo-Pacific Scyphomedusan new to the Mediterranean coast of Turkey. Isr J Zool 41:615-617

Kishinouye K (1922) Echizen kuarge (Nemopilema nomurai). Dobutsugaku Zasshi 34:343-346 (in Japanese)

Kramp PL (1961) Synopsis of the medusae of the world. J Mar Biol Assoc UK 40:1-569

Li DJ, Zhang J, Huang DJ, Wu Y, Liang J (2002) Oxygen depletion off the Changjiang (Yangtze River) Estuary. Sci China Ser D Earth Sci 45:1137-1146

Lotan A, Ben-Hillell R, Loya Y (1992) Life cycle of Rhopilema nomadica: a new immigrant Scyphomedusan in the Mediterranean. Mar Biol 112:237-242

Lotan A, Fine M, Ben-Hillel R (1994) Synchronization of the life cycle and dispersal pattern of the tropical invader scyphomedusan Rhopilema nomadica is temperature dependent. Mar Ecol Prog Ser 109:59-65

Lucas CH (2001) Reproduction and life history strategies of 
the common jellyfish, Aurelia aurita, in relation to its ambient environment. Hydrobiologia 451:229-246

Lucas CH, Lawes S (1998) Sexual reproduction of the scyphomedusa Aurelia aurita in relation to temperature and variable food supply. Mar Biol 131:629-638

Mianzan HW, Cornelius PFS (1999) Cubomedusae and Scyphomedusae. In: Boltovskoy D (ed) South Atlantic zooplankton. 1. Backhuys Press, Leiden, p 513-559

Möller H (1980) Population dynamics of Aurelia aurita medusae in Kiel Bight, Germany (FRG). Mar Biol 60:123-128

Naganuma K (1973) On discussions of the existence of the third branch of the Tsushima Current. Bull Jpn Sea Reg Fish Res Lab 266:1-3 (in Japanese)

Nishimura S (1959) Large occurrence of Nemopilema nomurai. Collect Breed 21:194-202 (in Japanese)

Nishimura S (1961) Large occurrence of Nemopilema nomurai: a supplement. Collect Breed (The Japan Science Society) 23:194-197 (in Japanese)

Omori M (1978) Zooplankton fisheries of the world: a review. Mar Biol 48:199-205

Omori M, Kitamura M (2004) Taxonomic review of three Japanese species of edible jellyfish (Scyphozoa: Rhizostomeae). Plankton Biol Ecol 51:36-51

Parsons TR, Lalli CM (2002) Jellyfish population explosions: revisiting a hypothesis of possible causes. Mer 40:111-121

Paspaleff BW (1938) Über die Entwicklung von Rhizostoma pulmo Agass. Trud Chernomorsk Biol Stn Varna 7:1-25 (in German with Bulgarian Abstract)

Purcell JE, Shiganova TA, Decker MB, Houde ED (2001) The ctenophore Mnemiopsis in native and exotic habitats: US estuaries versus the Black Sea basin. Hydrobiologia 451: 145-176

Russell FS (1970) The medusae of the British Isles. 2. Pelagic Scyphozoa with a supplement to the first volume on hydromedusae. Cambridge University Press, London

Editorial responsibility: Jennifer Purcell (Contributing Editor), Anacortes, Washington, USA
Shiganova TA, Bulgakova YV, Volovik SP, Mirzoyan ZA, Dudkin SI (2001) The new invader Beroe ovata Mayer, 1912 and its effect on the ecosystem in the northeastern Black Sea. Hydrobiologia 451:187-197

Shimomura T (1959) On the unprecedented flourishing of 'Echizen Kurage', Stomolophus nomurai (Kishinouye), in the Tsushima current regions in autumn, 1958. Bull Jpn Sea Reg Fish Res Lab 7:85-107 (in Japanese with English Abstract)

Silfen R, Vilan A, Wohl I, Leviav A (2003) Mediterranean jellyfish (Rhopilema nomadica) sting. Burns 29:868-870

Sugiura Y (1966) On the life history of rhizostome medusae. 4. Cephea cephea. Embryologia 9:105-122

Tanaka S, Suzuki T (2005) Remote sensing of the East China Sea concerning Nemopilema nomurai. Rem Sens Technol Jpn (RESTEC) 54:2-12 (in Japanese)

Uchida T (1954) Distribution of Scyphomedusae in Japanese and its adjacent waters. J Fac Sci Hokkaido Univ Ser VI Zool 12:209-219

Uye S, Ueta Y (2004) Recent increase of jellyfish populations and their nuisance to fisheries in the Inland Sea of Japan. Bull Jpn Soc Fish Oceanogr 68:9-19 (in Japanese with English abstract)

Yamada M (1997) Scyphozoa. In: Chihara M, Murano M (eds) An illustrated guide to marine plankton. Tokai University Press, Tokyo, p 541-547 (in Japanese)

Yasuda T (2004) On the unusual occurrence of the giant medusa Nemopilema nomurai in Japanese waters. Nippon Suisan Gakkaishi 70:380-386 (in Japanese)

Zhang J, Zhang ZF, Liu SM, Wu Y, Xiong H, Chen HT (1999) Human impacts on the large world rivers: Would the Changjiang (Yangtze River) be an illustration? Global Biogeochem Cycles 13:1099-1105

Zhang ML, Li M (1988) Study on the jellyfish Stomolophus meleagris stings in Beidehei. Med J China 68:449 (in Chinese)

Submitted: April 4, 2005; Accepted: July 17, 2005

Proofs received from author(s): December 12, 2005 